\title{
RESPONSIBILITAS PENGELOLAAN ANGGARAN PENDAPATAN DAN BELANJA DAERAH (APBD) KOTA BENGKULU
}

\author{
Septi Rindawati dan Marjoyo \\ Sekolah Tinggi Ilmu Administrasi (STIA) Bengkulu. \\ E-mail: septirindawati@yahoo.com
}

\begin{abstract}
ABSTRAK. Penelitian ini dilakukan guna mengetahui faktor apa yang menyebabkan rendahnya responsibilitas pengelolaan Anggaran Penapatan dan Belanja Daerah (APBD) Kota Bengkulu. Latar belakang dari penelitian ini adalah bahwa ketidak mampuan pemerintah dalam mempertanggungjawabkan pengelolaan anggaran dengan baik. Dengan metode kualitatif, penelitian ini menjadikan Walikota dan Pimpinan DPRD sebagai informan pangkal. Selain itu untuk mendapatkan data yang diperlukan dalam penelitian ini dilakukan observasi atas latar belakang penelitian seperti berbagai kegiatan dalam kaitannya dengan Responsibilitas pengelolaan APBD Kota Bengkulu. Simpulan dari penelitian ini adalah rendahnya responsibilitas pengelolaan APBD disebabkan oleh 6 (enam) faktor: Adanya struktur administrasi yang memusat, Sistim Administrasi yang ketinggalan zaman, Pembengkakan Birokrasi, Kompleksitas dan kekakuan peraturan, Struktur Gaji dan perpindahan pegawai, Kurangnya pelatihan dan pendidikan bagi aparat. Selanjutnya berkenaan dengan temuan penelitian, dapat diajukan sebuah konsep baru bagi pengembangan Ilmu Pemerintahan yakni : perilaku pejabat publik dalam pengelolaan anggaran.
\end{abstract}

Kata kunci: Responsibilitas, Pengelolaan, Anggaran

\section{BENGKULU MAYOR'S RESPONSILIBITY OF MANAGING REGIONAL BUDGET}

\begin{abstract}
The research Bengkulu Mayor's Responsibility of Managing Regional Budget to the Regional House of Representatives. This research aims to analyze the factors influencing the responsibility of managing the regional budget by mayor to the regional house. Another fact indicates that the inability of the regional goverments in responsibility. Regarding the qualitative method which is used in this research, Mayor's and DPRD leader were made first informants. Further, in order to get the necessary data, the writer have done some observations to the objects of this research, which are activities of the process on budgeting formulations, some documents concerning these activities, and other secondary dated about Bengkulu Mayor's Responsibility of Managing Regional Budget to the Regional House of Representatives. The results show that there are six factors by: The administrative structure of central system administration outdated, swelling bureaucracy, complexity and rigidity of rules, structure Salaries and migration officials, lack of training and education for officials, Further with respect to the research findings, it can convey a new concept for the development of the Government: the behavior of public officials in the management of the budget.
\end{abstract}

Keywords : Buggets management, regional goverment, responsibility

\section{PENDAHULUAN}

Peraturan perundang-undangan yang memuat struktur APBD sebagaimana yang ditetapkan dalam Peraturan Menteri Dalam Negeri Nomor 13 Tahun 2006 tentang Pedoman Pengelolaan Keuangan Daerah yang telah diubah dengan Peraturan Mendagri No. 21/2011 terdiri dari pendapatan daerah, belanja daerah, dan pembiayaan daerah. Khusus belanja daerah, belanja menurut kelompok belanja terdiri dari belanja tidak langsung (belanja aparatur) dan belanja langsung (belanja Publik).

Pengelolaan keuangan akan baik apabila aparat pemerintah mengutamakan pemahaman dan kesadaran mengenai pentingnya responsibilitas dalam pengelolaan anggaran membutuhkan komitmen dari seluruh pihak terkait, pemerintah, DPRD dan masyarakat. Keterlibatan masyarakat maupun DPRD bukan diartikan sekadar menghadirkan dalam berbagai pertemuan, rapat kerja, dialog interaktif atau apa pun namanya, tetapi apa yang dapat mereka (masyarakat dan DPRD) berikan terhadap pemecahan suatu masalah dalam pelaksanaan pemerintahan dan pembangunan.

Mengingat pengelolaan anggaran bagian dari politik, maka implementasi (realisasi) anggaran berdasarkan pengamatan penulis pada umumnya sarat dengan kepentingan politik. Kepentingan politik menentukan realisasi anggaran. Banyak program-program besar pemerintah daerah tidak dapat direalisasikan karena dihambat kepentingan politik stakeholder. Kepala daerah dan DPRD adalah dua stakeholder yang berkepentingan langsung dengan pengelolaan anggaran. Acapkali kepala daerah dan DPRD tidak harmonis dalam pengelolaan anggaran khususnya di Kota Bengkulu. Mereka mengedepankan kepentingan masing-masing. Kepala daerah membawa visi yang berbeda dengan DPRD. Anggaran dikelola berdasarkan kepentingan, bukan kinerja dan kebutuhan penting untuk pembangunan daerah. Perbedaan kepentingan dan visi memperburuk pengelolaan keuangan daerah sehingga pengelolaan anggaran diimplementasikan tanpa arah yang jelas. 
Kurang berpihaknya anggaran pemerintah kepada publik dimana anggarannya mayoritas dialokasikan guna memenuhi belanja pegawai. Seperti untuk membayar gaji, tunjangan, honor dan uang lembur. Biaya untuk belanja barang/jasa, perjalanan dinas, dan pemeliharaan gedung/ kendaraan semakin memperbesar kebutuhan anggaran untuk pegawai. Belanja pegawai yang menyedot biaya besar berdampak pada kecilnya anggaran untuk publik.. Kebanyakan daerah lebih dari $75 \%$ anggarannya digunakan dalam rangka membiayai internal birokrasi, sedangkan anggaran untuk pembangunan dan pelayanan publik relatif terbatas, sebagaimana di kutip dalam media harian rakyat Bengkulu. Seberapa jauh anggaran pemerintah berpihak pada publik, bisa diamati dari bagaimana pelayanan publik; seperti pelayanan kesehatan, pendidikan, dan pembangunan infrastruktur; diselenggarakan pemerintah.

Permendagri No 25/2009 tentang Pedoman Penyusunan APBD telah disebutkan guna mencapai sasaran pembangunan, dalam penyusunan program dan kegiatan daerah wajib menerapkan prinsip-prinsip efisiensi. Perjalanan dinas dan studi banding agar dibatasi frekuensi dan jumlah pesertanya serta dilakukan sesuai dengan substansi kebijakan yang sedang dirumuskan, yang hasilnya dilaporkan secara transparan dan akuntabel. Bahkan ditentukan pula pembatasan penganggaran untuk penyelenggaraan rapat-rapat yang dilaksanakan di luar kantor, workshop, seminar dan lokakarya.

Berdasarkan pengamatan dan yang tertera dalam APBD Kota Bengkulu, kepatuhan terhadap aturan tertulis tersebut tampaknya masih jauh dari harapan. Kurangnya sense of crisis Pemda juga terlihat dari tidak pekanya mereka atas kondisi masyarakat dan kondisi keuangan daerah. Sungguh ironis, meskipun masih banyak masyarakat yang terhimpit kesusahan ekonomi dan kondisi keuangan daerah yang terbatas, justru berencana memborong mobil dinas hingga miliaran rupiah.

Daerah semestinya memahami dan menempatkan prioritas pengalokasian anggarannya dengan tepat. Sebagaimana arahan Permendagri No 25/2009, masalah dan tantangan utama yang harus dipecahkan dan dihadapi. Di antaranya adalah upaya untuk menanggulangi kemiskinan, meningkatkan akses dan kualitas pendidikan, serta meningkatkan kualitas kesehatan. Di bidang pendidikan misalnya, Pemda secara konsisten dan berkesinambungan perlu mengupayakan pengalokasian anggaran pendidikan sekurang-kurangnya $20 \%$ dari belanja daerah.

Hal ini menunjukan bahwa anggaran yang dikelola tidak untuk diarahkan meningkatkan pelayanan pemerintahan serta kebutuhan masyarakat. Berdasarkan berbagai informasi mengenai rendahnya responsibilitas pengelolaan anggaran, terjadi karena rendahnya profesionalisme aparat kebijakan pemerintah yang tidak transparan, terhadap kontrol sosial, tidak adanya manajemen partisipatif, berkembang suburnya ideologi konsumtif dan hedeonistik dikalangan elit penguasa dan belum adanya code of conduct yang kuat yang diberlakukan bagi aparat di semua lini dengan disertai sangsi yang tegas dan adil. Untuk itulah maka perlu disusun agenda kebijaksanaan pengembangan responsibilitas publik bagi semua anggota birokrasi publik kita.

Permasalahan pemda Kota Bengkulu selama ini yang selalu muncul adalah ketidakmampuan menggunakan anggaran dengan tepat dimana anggaran yang dikelola tidak menggambarkan kebutuhan masyarakat yaitu dengan adanya pos-pos yang dibiayai APBD yang digunakan untuk kepentingan pejabat sangat kontras untuk kepentingan masyarakat.

Hal ini tidak sesuai dengan konsep pemerintahan yang bertanggung jawab yang dikemukakan oleh Herbert J. Spiro (1969:112), mengandung tiga konotasi:1. responcibility as accountability menunjukkan sejauhmana pelaku pemerintahan mampu menjalankan tugas/ perintah yang diamanatkan kepadanya. 2. Responcibility as obligation yaitu sejauhmana seorang pelaku pemerintahan menepati, menunaikan dan memenuhi janji baik kepada masyarakat, tuhan dan dirinya sendiri untuk bersedia memikul sangsi dari resiko. 3. Responcibility as causa/sebab akibat yaitu sejauhmana tingkat kepedulian seorang pelaku pemerintahan.

Dari literature review yang ditelusuri ditemui sejumlah penulis yang telah melakukan penelitian tentang masalah responsibilitas yang ditinjau dari berbagai berbagai sudut pandang sesuai masing-masing disiplin ilmu termasuk perdebatan makna responsibilitas itu sendiri dalam mewujudkan keperintahan yang baik.

Tetapi, studi ini tidak mengelaborasi secara detail bagaimana responsibilitas pengelolaan Anggaran Pendapatan dan Belanja Daerah (APBD) kepada Dewan Perwakilan Rakyat Daerah (DPRD) di Kota Bengkulu.

Selain dari itu, bahwa penelitian tentang APBD yang dilakukan selama ini lebih banyak membahas dan atau menganalisa tentang aspek pendapatan dan atau belanja yang berupa analisa atas penyelenggaraan APBD dan belum meneliti Responsibilitas pengelolaan APBD oleh Walikota kepada Dewan Perwakilan Rakyat Daerah (DPRD) terlebih bila dikaitkan dengan DPRD di lingkungan pemerintahan daerah Kota Bengkulu.

Berdasarkan latar belakang permasalahan, maka untuk mendeskripsikan, menganalisa, dan menginterprestasikan fokus permasalahan yang ada. Penulisan desertasi ini dirumuskan menjadi sebuah rumusan masalah sebagai berikut: Faktor apa yang menyebabkan rendahnya responsibilitas Pengelolaan Anggaran Pendapatan dan Belanja Daerah (APBD) oleh Walikota Kepada Dewan Perwakilan Rakyat Daerah (DPRD) Kota Bengkulu?.

Penelitian ini bertujuan untuk memperoleh pengetahuan empiris tentang permasalahan penelitian, 
yaitu: Untuk mengkaji dan menganalisis faktor yang menyebabkan rendahnya responsibilitas Pengelolaan Anggaran Pendapatan dan Belanja Daerah (APBD) oleh Walikota Kepada Dewan Perwakilan Rakyat Daerah (DPRD) Kota Bengkulu, sekaligus menemukan gagasan dan memperoleh konsep baru yang dapat memberikan kontribusi dalam pengembangan Ilmu Pemerintahan.

Kontribusi yang diharapkan dari penelitian ini adalah memberikan sumbangan pemikiran dan merumuskan pemikiran-pemikiran bersifat teoritis dalam rangka mengetahui faktor yang menyebabkan rendahnya responsibilitas Pengelolaan Anggaran Pendapatan dan Belanja Daerah (APBD) oleh Walikota Kepada Dewan Perwakilan Rakyat Daerah (DPRD) Kota Bengkulu Selanjutnya hasil tulisan ini juga dapat menjadi masukan yang berarti bagi pengembangan ilmu sosial khususnya Ilmu Pemerintahan dan sebagai bahan acuan/rujukan dalam pengkajian masalah-masalah yang terkait dengan faktor yang menyebabkan rendahnya responsibilitas pengelolaan Anggaran Pendapatan Dan Belanja Daerah (APBD) oleh Walikota kepada Dewan Perwakilan Rakyat Daerah (DPRD) Kota Bengkulu.

\section{METODE}

Berdasarkan masalah penelitian yang dirumuskan oleh penulis, maka rancangan penelitian yang digunakan adalah rancangan penelitian kualitatif, sehingga melalui penelitian ini didapatkan konsep baru atas masalah yang diteliti. Penelitian deskriptif memiliki tujuan untuk menggambarkan secara tepat sifat seseorang individu, gejala, keadaan atau kelompok tertentu atau untuk menentukan frekuensi/ penyebaran suatu gejala lain dalam masyarakat, sebagaimana yang dikemukakan oleh Sugiyono (2007:12), penelitian kualitatif adalah penelitian yang digunakan untuk meneliti pada kondisi objek alamiah dimana peneliti merupakan instrumen kunci.

Dengan demikian maka yang menjadi fokus penelitian ini adalah Faktor yang menyebabkan rendahnya responsibilitas Pengelolaan Anggaran Pendapatan Dan Belanja Daerah (APBD) oleh Walikota kepada Dewan Perwakilan Rakyat Daerah (DPRD) Kota Bengkulu. Dalam rangka untuk lebih memahami permasalahan dalam penelitian ini diperlukan data dengan menggunakan metode wawancara dan observasi serta pemanfaatan dokumen tertulis. Sedang penyajian data dan informasi dideskripsikan dalam bentuk kalimat yang lebih bermakna dan mudah dipahami.

Pendalaman wawancara dilakukan di tingkat Pemerintah Daerah Kota dalam hal ini adalah: (1) Walikota, (2)Aparat Pemkot (Tim Anggaran Pemerintah Daerah), anggota panggar Dewan Perwakilan Rakyat Daerah (DPRD) Kota Bengkulu, serta tokoh masyarakat.

Adapun penentuan informan dilakukan menurut tujuan tertentu, artinya hanya dipilih informan yang memenuhi syarat (kaya informasi) yaitu informasi yang benar-benar banyak mengetahui data tentang objek yang diteliti. Selain itu informan juga mampu mengungkapkannya dengan jelas untuk mempresentasikan setting individu, aktifitas dan menggambarkan karakteristik responden. Penentuan informan dalam penelitian ini didasarkan atas kriteria bahwa informan adalah pelaku atau orang yang terlibat dalam pengelolaan Anggaran Pendapatan Dan Belanja Daerah (APBD) Kota Bengkulu.

Proses pengambilan informan dalam penelitian ini, mula-mula ditetapkan informan kunci (key informan) yaitu orang-orang yang memberikan informasi atau data berupa kata-kata dan tindakan terkait masalah yang diteliti. Adapun informan yang dibutuhkan disesuaikan dengan informasi yang dibutuhkan dalam mengungkap secara utuh, komprehensif dan objektif terhadap masalah yang diteliti, yakni Faktor yang menyebabkan rendahnya responsibilitas Pengelolaan Anggaran Pendapatan dan Belanja Daerah (APBD) oleh Walikota kepada Dewan Perwakilan Rakyat Daerah (DPRD) Kota Bengkulu. Informan kunci (keyinforman) ditiap-tiap pengelompokan kompetensi dan bidang kerja (stakeholders) tersebut kemudian diminta untuk menentukan atau menunjuk pihak lainnya yang akan dijadikan sebagai informan. Demikian seterusnya, sehingga informan ditiap pengelompokan tersebut bertambah seperti bola salju (snowball sampling). Penunjukan informan dirasa cukup pada setiap pengelompokan tersebut (stakeholders), jika data atau informasi yang diperlukan dirasakan sudah cukup atau jawaban yang diperoleh mulai berulang dari informan yang satu ke informan lainnya.

Informan-informan tersebut masing-masing para aktor yang mempunyai kewenangan pengambil kebijakan, dan terlibat tawar-menawar. Di tingkat Pemerintah Daerah Kota dalam hal ini adalah : (1) Walikota, (2) Aparat Pemkot sebanyak 5 orang, Bepeda Kota Bengkulu (Tim Anggaran Pemerintah Daerah sebanyak 7 orang ), anggota panggar Dewan Perwakilan Rakyat Daerah (DPRD) Kota Bengkulu sebanyak 5 orang, serta tokoh masyarakat sebanyak 4 orang.

Teknik pengumpulan data dalam penelitian ini dilakukan melalui (Creswell, 1994; 44) sebagai berikut: (a) Wawancara dilakukan secara terbuka dengan sumbersumber data yang kompeten; yakni peneliti mendatangi informan dan berdialog secara mendalam mengenai masalah penelitian. Pada umumnya wawancara dilakukan oleh penulis terhadap informan di tempat kerja, walaupun ada di antaranya yang dilakukan di tempat tinggal atau di tempat lain sebagaimana kesediaan informan yang diwawancarai. Teknik wawancara yang digunakan adalah pendekatan dengan menggunakan petunjuk umum wawancara terutama ketika wawancara dengan informan tunggal.(b) Studi dokumentasi untuk menelusuri bukti-bukti berupa dokumen tertulis maupun elektronik dari lembaga/institusi yang terkait dalam penelitian ini; perilaku individu, perilaku kelompok dan 
perilaku organisasi, pejabat politik, dokumen perencanaan pembangunan di daerah, dan pengelolaan APBD. Kegiatan Penelusuran literatur dilakukan di perpustakaan Universitas Padjadjaran, Internet dan toko-toko buku. (c) Observasi dengan merekam data-data primer berupa peristiwa atau situasi sosial tertentu pada lokasi penelitian yang berhubungan dengan fokus penelitian. Observasi atas berbagai kegiatan yang berkaitan dengan pengelolaan APBD di Kota Bengkulu. Kemudian observasi langsung secara intensif dilakukan peneliti atas pengelolaan APBD Kota Bengkulu tahun 2012, setelah peneliti mendapat ijin dari pemerintah Kota Bengkulu sebagaimana surat ijin nomor 070.1/528/I/BPPT dan PM/2013 tentang izin penelitian.

Keabsahan (validasi) data sangat diperlukan dalam penelitian. Teknik pengujian keabsahan data dalam penelitian ini adalah dengan triangulasi. Triangulasi dilakukan dengan memeriksa kembali kebenaran data yang diperoleh melalui studi dokumentasi, pengamatan, maupun wawancara. Sehingga dapat diolah menjadi informasi yang berkaitan dengan fenomena penelitian, yang meliputi spesifikasi, penilaian, analisis dan rekomendasi tentang faktor yang menyebabkan rendahnya responsibilitas Pengelolaan Anggaran Pendapatan Dan Belanja Daerah (APBD) oleh Walikota kepada Dewan Perwakilan Rakyat Daerah Kota Bengkulu.

Teknik triangulasi ini dilakukan untuk pemeriksaan keabsahan data yang memanfaatkan sesuatu yang lain di luar data untuk keperluan pengecekan atau sebagai pembanding terhadap data itu. Selain itu teknik triangulasi dapat meningkatkan kedalaman pemahaman peneliti baik mengenai fenomena yang diteliti maupun konteks di mana fenomena itu muncul. Bagaimana pun, pemahaman yang mendalam (deep understanding) atas fenomena yang diteliti merupakan nilai yang harus diperjuangkan oleh setiap peneliti kualitatif. Sebab, penelitian kualitatif lahir untuk menangkap arti (meaning) atau memahami gejala, peristiwa, fakta, kejadian, realitas atau masalah tertentu mengenai peristiwa sosial dan kemanusiaan dengan kompleksitasnya secara mendalam.

Triangulasi dapat dilakukan dengan teknik yang berbeda menurut Nasution (2003:115) yaitu wawancara, observasi dan dokumen. Triangulasi ini selain untuk mengecek kebenaran data juga dilakukan untuk memperkaya data. Menurut Nasution, selain itu triangulasi juga dapat berguna untuk menyelidiki validitas tafsiran peneliti terhadap data, karena itu triangulasi bersifat reflektif.

Menurut Sugiyono triangulasi diartikan sebagai teknik pengumpulan data yang bersifat menggabungkan dari berbagai teknik pengumpulan data dan sumber data yang telah ada sekaligus menguji kredibilitas data, yaitu mengecek kredebilitas data dengan teknik pengumpulan data dan berbagai sumber data.

Triangulasi teknik, berarti menggunakan teknik pengumpulan data yang berbeda-beda untuk mendapatkan data dari sumber yang sama dengan menggunakan observasi partisipatif, wawancara yang mendalam, dan dokumentasi untuk sumber data yang sama secara serempak. Triangulasi sumber berarti, untuk mendapatkan data dari sumber yang berbeda-beda dengan teknik yang sama.

Berdasarkan uraian di atas proses triangulasi penelitian ini dimulai dari data yang diperoleh melalui pengamatan (observatori-partisipatoris) dan melalui wawancara, diformatkan dalam kata-kata kunci. Sedangkan singkatan dan kalimat-kalimat penting diberikan kode khusus. Selain dari itu data dijaring pula melalui penelusuran dokumen dan data statistik, yang kemudian dibuat jaringan antar sumber data yang satu dengan yang lainnya, yang dapat menggambarkan kegiatan check, recheck dan cross check di antara informan 1, 2, 3, 4 dan seterusnya sebagai sumber data dan informasi penelitian, yang hasilnya akan menyempurnakan data dan informasi yang sudah ada. Dalam pelaksanaan penelitian check, recheck dan cross-check tersebut dilakukan lebih mendalam apabila terjadi perbedaan data dan informasi antara satu informan dengan informan lainnya atau apabila dipandang perlu untuk memperdalam pencarian data dan informasi. Selain dari itu proses triangulasi dilakukan pula dengan mencocokkan data yang diterima dengan teori yang ada sebelumnya, yang dilakukan secara simultan pada saat pengumpulan data, sehingga apabila terjadi penyimpangan dapat dilakukan konfirmasi secara langsung kepada informan yang menyampaikannya.

Tahapan analisis diolah melalui tahap analisis yang terdiri dari tiga komponen pokok, yaitu: a. Reduksi data, merupakan proses pemilihan, pemusatan perhatian pada penyederhanaan, pengabstrakkan, transformasi data kasar yang muncul dalam catatan-catatan tertulis di lapangan. b. Sajian data merupakan rakitan organisasi informasi yang memungkinkan pengambilan kesimpulan riset, dan pengambilan tindakan berdasarkan atas pemahaman yang didapat dari penyajian data tersebut. Penyajian data tersebut dilakukan dengan sistematis, melalui gambar / skema, jaringan kerja yang berkaitan dengan kegiatan atau tabel. Semua itu dirancang guna merakit informasi secara teratur supaya penelitian dan hasil-hasilnya mudah dilihat dan dimengerti. c. Menarik kesimpulan / verifikasi merupakan proses mengartikan segala hal yang ditemui selama penelitian dengan melakukan pencatatan, peraturan-peraturan, pola-pola pernyataan-pernyataan, konfigurasi-konfigurasi yang mungkin, arahan sebabakibat, dan proposisi-proposisi, dengan kata lain tahap ini merupakan proses untuk menarik kesimpulan terhadap apa yang didapat selama penelitian itu dilakukan.

Ketiga komponen analisis tersebut diatas bekerja membentuk interaksi dengan proses pengumpulan data, dan interaksi tersebut bersifat siklus. Dalam bentuk ini, peneliti bergerak diantara ketiga komponen pokok dan komponen pengumpulan data selama proses pengumpulan data berlangsung. Setelah mengadakan 
pengumpulan data, kemudian bergerak diantara reduksi data, sajian data dan verifikasi dengan memanfaatkan waktu yang ada selama penelitian.

\section{HASIL DAN PEMBAHASAN}

Pada bagian ini dibahas data hasil penelitian yang diperoleh dari lapangan melalui tiga teknik pengumpulan data yaitu wawancara secara terbuka dengan sumbersumber data yang kompeten, observasi lapangan dan studi dokumentasi. Setelah itu memeriksa kembali kebenaran data yang diperoleh dengan membaca semua transkrip, reduksi data sehingga dapat diolah menjadi informasi yang berkaitan dengan fokus kajian. Kemudian melakukan keabsahan data dengan proses triangulasi yaitu dengan mencocokkan data yang diterima dengan teori yang ada kemudian dianalisis atau pembahasan. Pembahasan terhadap data yang diperoleh dari lapangan dilakukan melalui metode interprestasi sebagaimana yang biasa dilakukan dalam penelitian kualitatif.

Analisis ini dilakukan dengan cara mengelaborasi lebih detail pada masing-masing bagian yang dimaksud bukan sebagai sebuah dimensi sebagaimana yang biasa dilakukan dalam penelitian kualitatif. Namun demikian lebih dimaksud sebagai pengelompokan atau katagorisasi untuk mempermudah pemahaman dan eksploitasi terhadap data yang diperoleh di lapangan. Mengacu pada isu pokok dan permasalahan sebagaimana yang telah diuraikan dalam latar belakang masalah, untuk menjelaskan maksud atau fokus yang akan di analisa bahwa terdapat beberapa faktor penyebab rendahnya responsibilitas pengelolaan APBD oleh Walikota kepada DPRD Kota Bengkulu. Faktor-faktor yang menyebabkan rendahnya responsibilitas dalam pengelolaan anggaran antara lain :

1. Adanya Struktur Administrasi yang memusat, sehingga tidak bisa di kontrol dalam menggunakan kekuasaannya yang dapat berakibat mengorbankan kepentingan masyarakat luas dan terdapatnya kepentingan-kepentingan politik dan individu dari pejabat yang memiliki kekuasaan. Dengan adanya hierarki antara pemerintahan kabupaten/kota dengan propinsi, sesungguhnya tidak berpengaruh terhadap pengendalian yang harus dilaksanakan oleh gubernur terhadap pemerintahan kabupaten/kota dalam kaitannya dengan pengelolaan APBD, tetapi dengan adanya sistem sentralisasi administrasi yang mempunyai rentang kendali dan garis komando yang panjang, sehingga menimbulkan kesulitan dalam pengawasan dan distorsi perintah yang menyebabkan bawahan terlampau mengandalkan kemampuan pimpinan dan sedikit sekali menyampaikan masalahmasalah riil yang dijumpainya untuk dipecahkan.

Hal penting dalam pengelolaan APBD yang efektif dan efisien adalah komitmen para pihak yang terlibat. Aparatur sipil negara yang berada dalam struktur organisasi pemerintahan daerah (SKPD), Tim Anggaran Pemerintah Daerah (TAPD) dan Panitia Anggaran DPRD merupakan pihak yang sangat menentukan ketepatan penyelesaian jadwal penyusunan dan pengelolaan APBD. Selain itu melaksanakan tugas sesuai dengan ketentuan peraturan perundang-undangan yang berlaku bahwa aparatur negara juga harus profesional dengan karakteristik adaptif, berintegrasi, berkinerja tinggi, bebas KKN, harus mampu memberikan pelayanan kepada publik secara maksimal, netral, berdedikasi serta memegang teguh nilai-nilai aparatur negara.

2. Sistem Administrasi yang Ketinggalan Zaman adalah sistem administrasi yang masih tradisional dengan fasilitas fisik dan teknis yang tidak memadai sehingga menghasilkan arus informasi yang tidak sistematik, lemahnya koordinasi, kurangnya perencanaan yang komprehensif, sulitnya pengendalian dan pengawasan, serta inefisiensi. Contohnya: $a$. website Pemerintah Daerah Kota Bengkulu tidak menampilkan informasi mengenai seluruh Laporan Hasil Reviu maupun hasil pemeriksaan yang dilakukan oleh Aparat Pengawas Internal Pemerintah (APIP) seperti Inspektorat Kota dan BPKP maupun BPK selaku aparat aparat eksternal.

Hal ini sesuai pendapatDjalil(2014) Tidak tersedianya teknologi yang dapat mendukung kelancaran kerja merupakan faktor penghambat yang cukup serius bagi terselenggaranya pemerintahan yang baik.

Identifikasi, adanya sistem administrasi yang ketinggalan zaman karena Pemerintah Kota Bengkulu belum bersungguh-sungguh melibatkan partisipasi masyarakat; misalnya, tokoh masyarakat, LSM, media massa, website, perguruan tinggi, baik dalam proses perumusan kebijakan maupun dalam perencanaan anggaran, demikian juga dengan masalah transparansi. Karena kelemahan-kelemahan tersebut, para penyelenggara pemerintahan daerah tidak terpacu untuk meningkatkan kinerja secara lebih baik, karena lemahnya pengawasan dari masyarakat.

3. Pembengkakan Birokrasi Yaitu membentuk organisasi perangkat daerah yang banyak jumlahnya dan kurang didasarkan pada kebutuhan nyata dari daerah menimbulkan terjadinya pembengkakan perangkat daerah. "Dampak lebih jauh mengakibatkan sebanyak 70-80 persen APBD habis atau tersedot untuk pembiayaan birokrasi dan aparatur.

Selain itu kelemahan dengan banyaknya perangkat daerah mengakibatka prosedur yang berlebihan akan mengakibatkan pelayanan menjadi berbelit-belit dan kurang menguntungkan bagi masyarakat ketika dalam keadaan mendesak, penambahan perangkat daerah dapat dilakukan dengan menambah jumlah struktur pada birokrasi dengan alasan untuk meringankan beban kerja dan lain-lain yang sebenarnya struktur tersebut tidak terlalu diperlukan keberadaannya, yang 
akhirnya akan banyaknya pula kementerian baru yang dibuat oleh pemerintah lebih sering tidak didasarkan pada suatu kebutuhan untuk merespon kepentingan masyarakat agar lebih terwadahi tetapi lebih kepada motif tertentu.

Pembengkakan birokrasi akan menjadi masalah yaitu dapat dilihat dari besarnya belanja pegawai karena besarnya beban pembayaran gaji dan tunjangan PNS, hal ini dapat merugikan masyarakat, kemudian juga dapat mempengaruhi kualitas pelayanan publik membuat masyarakat sangat kecewa karena masyarakat belum dapat menikmati pelayanan prima baik dari segi kualitas maupun ketepatan waktu. Sehingga situasi seperti ini juga mengakibatkan pengawasan, pengendalian dan koordinasi sangat sulit dilaksanakan.

4. Kompleksitas dan kekakuan peraturan

Peraturan dan berbagai ketentuan yang ada dalam kaitannya dengan pengelolaan APBD masih menyediakan ruang yang sangat luas untuk ditafsirkan oleh para penyusun APBD baik di lingkungan pemerintah daerah, maupun di DPRD. Terlebih lagi dengan belanja bantuan sosial yang terakhir diatur dalam permendagri nomor 59 tahun 2007, yang seolah-olah setiap kegiatan dapat didanai dengan belanja bantuan sosial. Hal ini seringkali tidak memperhatikan tentang etika dan keadilan.

Berdasarkan hal tersebut sesungguhnya bagi Walikota sebagai kepala eksekutif pemerintahan daerah dan bagi DPRD sebagai pelaksana fungsi legislatif pemerintahan daerah, diperlukan formalisasi yang lebih tegas yang akan membimbing Walikota dalam pertanggung jawaban administratif dan membimbing DPRD agar anggaran sesuai dengan norma-norma etik dan moral serta berorientasi pada keadilan. Kemudian dengan memperhatikan kedudukan dan struktur organisasi di mana para pejabat politik berada dan terutama untuk anggota DPRD yang bersifat kolegial, maka sudah seharusnya para pejabat politik terikat dengan aturan internal yang disepakati dan dijalankan sendiri. Aturan-aturan dimaksud berisikan nilai-nilai dan landasan etik yang disepakati, tentang sesuatu yang boleh dan tidak boleh dilakukan oleh pejabat politik dalam menjalankan kedudukan, tugas dan fungsinya.

5. Struktur gaji dan perpindahan pegawai:

Ini merupakan isu paling kompleks dan sensitif dalam sistem administrasi kepegawaian karena mempunyai dampak langsung terhadap efisiensi, moral dan Akuntabilitas aparat sekaligus juga berpengaruh terhadap kemampuan pemerintah untuk merekrut dan mempertahankan pegawai yang cakap dan akuntabel. Permasalahannya:

a. Pemerintah Kota Bengkulu mengalokasikan APBD lebih dari 50 persen untuk belanja pegawai. Konsekuensi dari besarnya porsi APBD untuk belanja pegawai realisasinya Rp. 437.795.578.379 atau sekitar 95,40\% hal ini menunjukkan angka yang terus bertambah dari tahun sebelumnya. Peningkatan tersebut terjadi karena adanya pegawai baru, kenaikan gaji berkala maupun peningkatan pangkat/jabatan. Hal ini berdampak langsung pada semakin kecilnya belanja untuk rakyat. Kemampuan daerah mendorong perbaikan pelayanan dan pembangunan infrastruktur menjadi tersendat. Pembiayaan subsidi juga makin terkurangi.

b. Permasalahan selanjutnya bisa terjadinya korupsi, kolusi dan nepotisme $(\mathrm{KKN})$ dalam penetapan gaji dan promosi perpindahan pegawai. Contohnya Sistem penggajian tidak memiliki kriteria kinerja yang melekat di dalam sistem tersebut. Juga tidak terdapat hukuman atas korupsi dan mutu kinerja yang rendah. Sehingga, menjadi pegawai negeri walaupun gajinya kecil tetap merupakan pilihan yang menarik, dan tidak terjadi kekurangan lamaran untuk posisi-posisi pegawai negeri

Hal ini senada dengan Mariana (2010;55) bahwa secara operasional sejumlah peraturan ditetapkan sebagai landasan yuridis bagi pembenahan birokrasi melalui rancangan peraturan tentang penempatan pegawai, karier pegawai, dan peningkatan gaji pegawai negeri.

6. Kurangnya pelatihan \& rendahnya pendidikan aparat. Minimnya SDM pendukung dalam hal pelatihan dan pendidikan akan berimplikasi terhadap pengelolaan APBD sehingga anggaran tidak dapat direalisasikan dengan baik. Faktanya: pada umumnya anggota DPRD kurang memiliki kemampuan berkenaan dengan proses pengelolaan APBD. Hal ini dapat dilihat, bahwa sebagian besar anggota DPRD Kota Bengkulu adalah mereka yang baru pertama kali terpilih menjadi anggota DPRD, dan mempunyai latar belakang pendidikan serta pengalaman kerja yang beragam, yang pada umumnya tidak berkaitan dengan masalah-masalah pemerintahan.

Hal ini sependapat dengan Yuwono (2008;45) mengatakan bahwa agar mampu menjalankan tugasnya dengan baik, DPRD seharusnya tidak hanya mempunyai kemampuan di bidang politik, tetapi juga pengetahuan yang cukup mengenai mekanisme kerja DPRD, kebijakan publik, konsep dan teknik pemerintahan, teknik pengawasan, dan sebagainya. Dalam pengadaan barang dan jasa pada Pemerintah Daerah Kota Bengkulu belum maksimal, seperti kurang lengkapnya dokumentasi tentang proses pengadaan barang dan jasa pemerintah, dan juga dokumentasi laporan realisasi fisik dan adminitrasi keuangan kegiatan pengadaan barang dan jasa. Hal ini karena SDM pengelola pengadaan barang 
dan jasa tidak memiliki kapasitas yang memadai untuk dapat melaksanakan pengadaan barang dan jasa sesuai ketentuan.

Pemda Kota Bengkulu yang lulus sertifikasi nasional pengadaan barang dan jasa bertugas di Dinas PU Kota Bengkulu Bengkulu sebanyak 238 personil dan tidak merata dari distribusi personil, karena $42.6 \%$ dari seluruh personil yang memiliki sertifikat pengadaan terpusat hanya pada satu intansi, sedangkan pada intsansi lain ada yang belum memiliki pegawai yang lulus sertifikasi pengadaan.

7. Perilaku Pejabat Publik dalam Pengelolaan Anggaran. Faktor yang mempengaruhi rendahnya pertanggungjawaban dalam pengelolaan anggaran juga dipengaruhi oleh perilaku pejabat publik karena dalam proses penyusunan sampai pada pengelolaan anggaran tidak saja melibatkan peran pejabat publik daerah, tetapi seharusnya melibatkan unsurunsur yang diperintah dan termasuk didalamnya partai politik, kelompok-kelompok kepentingan, dan atau kelompok organisasi kemasyarakatan serta masyarakat itu sendiri. Pentingnya keikutan seluruh stakeholders dalam pengelolaan anggaran, karena anggaran memiliki arti penting berkenaan dengan berkesinambungan pembangunan dan upaya pemenuhan kebutuhan masyarakat yang tidak terbatas.

Cara bertindaknya anggota DPRD yang cenderung personal dan tidak institusional, sehingga seringkali mereduksi sikap-sikap institusi ke dalam individual di dalam perumusan kebijakan publik dan terlebih lagi dalam pengelolaan anggaran.

Keadaan di atas seharusnya tidak terjadi karena sebagaimana dikemukakan oleh Yowono (2008:154) bahwa tujuan prioritas APBD adalah terpenuhinya skala kebutuhan masyarakat yang paling penting dan paling luas jangkauannya agar alokasi sumberdaya dapat digunakan dan dimanfaatkan secara ekonomis, efisiensi dan efektif mengurangi tingkat resiko dan ketidak pastian serta tersusunya program dan kegiatan yang realistis.

Berdasarkan permasalahan di atas tampak bahwa arah kebijakan anggaran yang hendak dicapai belum nampak, walaupun dalam kebijakan umum anggaran telah ditegaskan bahwa APBD Kota Bengkulu harus berorientasi pada upaya pengentasan kemiskinan dan penyediaan lapangan kerja.

\section{SIMPULAN}

Makna Responsibilitas disini yaitu mengaplikasikan makna responsibility bagi pemerintah dalam tiga pengertian yakni accountability, obligation dan cause Pemerintah dimaksud. Dengan demikian, disampulkan bahwa perwujudan makna pemerintah yang bertanggung jawab kepada rakyat merupakan nilai esensial tau satu inti sari dari terwujudnya suatu pemerintahan yang legitim. Dengan kata lain, legitimiasi pemerintahan hanya dapat tercipta manakala suatu pemerintahan dapat mempertanggungjawabkan segenap pelaksanaan kekuasaan, wewenang dan pengaruhnya kepada seluruh rakyat secara demokratis.

Berdasarkan hasil pembahasan bahwa yang menyebabkan rendahnya Responsibilitas pengelolaan Anggaran dan Pendapatan Daerah (APBD) dari Walikota kepada DPRD Kota Bengkulu dipengaruhi oleh 6 (enam) faktor. Selanjutnya berkenaan dengan temuan penelitian, penulis dapat menyampaikan sebuah konsep baru bagi pengembangan Ilmu Pemerintahan yakni: rendahnya responsibilitas disebabkan oleh faktor kondisi politik daerah karena setiap peralihan kepala daerah sering juga di ikuti pergantian jabatan sehingga tidak ada profesional jabatan.

Untuk mengatasi faktor yang mempengaruhi rendahnya responsibilitas pengelolaan anggaran yaitu Harus ada komitmen dari pemerintah daerah dan Dewan Perwakilan Rakyat (DPRD) untuk meninjau ulang regulasi pusat yang menghambat daerah mendapatkan hasil-hasil eksploitasi sumberdaya alam secara lebih adil, mengembangkan keahlian tekhnis sumberdaya manusia dalam menggali potensi sumberdaya alam dan mengelolanya secara lebih efisien dan efektif. Termasuk dalam hal ini adalah kebijakan kepala daerah dalam merotasi dan memutasi pegawai harus memperhatikan keahlian teknis pegawai yang bersangkutan. Dengan kata lain, kepala daerah tidak terlalu sering merotasi dan memutasi pegawai yang memiliki keahlian teknis, khsususnya dalam penganggaran serta melaksanakan pelatihan ditujukan bagi eksekutif (TAPD) dan bagi legislatif untuk membangun komitmen yang lebih tinggi dalam pemenuhan nilainilai kualitas belanjda daerah dan perumusan APBD.

Bagi Pemeritah Pusat, peninjauan kembali regulasi yang berkaitan dengan hak-hak. daerah dalam mengelola sumberdaya alam dimaksudkan agar daerah menjadi lebih besar kewenangannya sehingga memperoleh pendapatan dari eksploitasi sumberdaya alamnya secara lebih adil.

\section{DAFTAR PUSTAKA}

Bambang dkk, Dampak transfer Pemerintah Pusatter hadap penuruan letimpangan Pendapatan di Indonesia, Jurnal sosiohumaniora Unpad edisi Juli 2013 vol 15 no. 2

Nasution, 2003. Metode Penelitian Naturalistik Kualitatif. Bandung Tarsito 
Spiro, Herbert, J., 1969, Responsibility in Government, Van Nostrand Reinhold Company, New York.

Sugiyono. 2007. Metode Penelitian. Cetakan Ketujuh. CV. Alfabeta. Bandung.

Djalil, Rizal, 2014. Akuntabilitas Keuangan Daerah. PT. Semesta Rakyat Merdeka

Mariana, Dede dan Caroline Paskarina, 2010. Merancang Reformasi Birokrasi di Indonesia. Asosiasi Ilmu Politik Indonesia (AIPI) Bandung dan Puslit KPK-LPPM Unpad

Yuwono, Sony, Utomo,Cahyo, Dwi, Zein Suheiry,H, Azrafiany,A R, H. , 2008, Memahami APBD dan Permasalahannya (Panduan Pengelolaan
Keuangan Daerah), Malang: Bayu Media Publishing

Peraturan Pemerintah Republik Indonesia Nomor 8 Tahun 2006 tentang Pelaporan Keuangan dan Kinerja Instansi Pemerintah.

Peraturan Pemerintah Nomor 3 Tahun 2007 tentang laporan penyelenggaraan pemerintahan daerah kepada pemerintah, laporan keterangan pertanggungjawaban kepala daerah kepada Dewan Perwakilan Rakyat Daerah dan Informasi Laporan Penyelenggaraan Pemerintah Daerah kepada masyarakat

Peraturan daerah Kota Bengkulu tentang anggaran pendapatan dan belanja Kota Bengkulu 